\title{
Absorption and Accumulation of Heavy Metal Pollutants in Roadside Soil-Plant Systems - A Case Study for Western Inner Mongolia
}

\author{
Lu Zhanyuan", Zhi Yingbiao $23^{*}$, Wang Zai-lan,, \\ Hua Yupeng 2 , Hong Ge ${ }^{2}$, Emmy Camada ${ }^{5}$ and Yao Yiping ${ }^{1}$ \\ IInner Mongolia Academy of Agricultural Science, Hohhot, \\ ${ }^{2}$ Ordos College, Inner Mongolia University, Ordos, \\ ${ }^{3}$ College of Life Science, Nanjing University, Nanjing, \\ ${ }^{4}$ School of Environment and Natural Resources, \\ Renmin University of China, Beijing, \\ ${ }^{5}$ Chinese Culture Center of San Francisco, CA, \\ $1,2,3,4$ China \\ ${ }^{5}$ USA
}

\section{Introduction}

Soil - plant system is the biosphere and pedosphere whose the basic structural unit of soil is the main target. Soil - plant systems enable human productivity but suffer from pollution damage caused by humans. Currently, the annual loadings of harmful metals in soil are (104 t / a): $\mathrm{Hg}$ 0.83, Cd 2.2, Cr 89.6, Pb 79.6, Ni 32.5, Cu 95.4, Zn 137.1, As 8.1, Se 4.1 [1,2]. Contaminated soil will directly, or by amplifying through the food chain, affect the normal function and growth of plant and even human health. At the same time, the ecosystem, through a series of physical, chemical and biological processes in the environment, provides a purification of pollutants. Beyond the loading capacity of the environmental pollution load capacity and super-threshold, its biological production will be affected, resulting in severe loss of productivity and may even directly or indirectly endanger human life and health. Phytoremediation is considered a green technology for the removal of heavy metal pollution in the ascendant [3]. With the rapid development of the national economy and the subsequent traffic pollution, negative environmental effects are becoming increasingly apparent, especially for roadside soil - plant systems. The the evidence is apparent in Shanxi Province where $5,000 \mathrm{~km}$ of roadside farmland was polluted by coal dust, reducing food productivity by $2800 \times 10^{4} \mathrm{~kg}$ [4]. In recent years, car exhaustion and road dust caused heavy metal pollution on the soil-plant systems on both sides of the roads, and consequently, the heavy metal content has brought stress on the structure and function of ecosystem, which increasingly exposed agricultural issues. Currently, research on the domestic and international distribution of heavy metals in soil

${ }^{*}$ Corresponding Author 
on both sides of the road have been reported [5-10]. At the same time, studies on heavy metal pollution on soil-plant systems on both sides of the road have been carried out [11-17], but only limited studies are conducted on the heavy metal absorption and accumulation on the highway [18]. With the rapid development of the regional economy, the western region of Inner Mongolia produces more coal, building materials, and chemical products, and the rapid increase in traffic and road transport vehicles increased significantly [19]. In 1992, the average traffic in the Inner Mongolia Autonomous Region were 731 vehicles per day. By the end of 2004, the average number of traffic had increased to 5171 per day, of which 2533 are State Roads with G109 vehicles / day, G210 are State Roads with 4946 vehicles / day, and G110 are National Roads with 6739 vehicles / day. With heavy road traffic and associated problems of automobile exhaust emissions becoming more evident, it is necessary to have studies on the accumulation of heavy metals and the potential ecological risk assessment. Therefore, in this study western Inner Mongolia Transport heavy G110 National Road, G210 National Highway and the G109 National Road are selected as study objects, along with highway green vegetable pine (Pinus tabulaeformis Carr.) and lobular Yang (Populus simonii Carr.) Heavy metal absorption and accumulation and heavy metals in rhizosphere soil and the relationship between distribution and morphology to the road along the soil - plant system bioremediation of heavy metals are investigated to provide theoretical reference.

\section{Material and methods}

\subsection{Material}

\subsubsection{Characteristics of the study area}

According to the study area $\left(106^{\circ} 35^{\prime} \sim 111^{\circ} 36^{\prime} \mathrm{E}, 38^{\circ} 56^{\prime} \sim 42^{\circ} 28^{\prime} \mathrm{N}\right)$ and vegetation characteristics, soil type and parent material conditions, the different sampling points are divided into three types (Figure 1). Specifically: Hohhot - Baotou - Wuyuan - Linhe Dengkou located Tumochuan and Hetao plains, there it is high underground water level and high salinity, vegetation intrazonal Salt meadow-based, low land vegetation,and zonal soil type is meadow soil, and now most of the land has been opened Cultivated as farmland: Wuhai - Uda - Etuog County - Hangjin County there the vegetation dominated by grassland desertification, desert region in western China is a special area, zonal soil type is brown soil; Dongsheng - Zhunger, Yijinhuoluo - Dongsheng - Dalate located Ordos Plateau in the east, the vegetation's Stipa (Stipa bungeana) constructive species of warm temperate typical steppe, but the long-term cultivation, overgrazing, native natural vegetation has been destroyed, therefore, there is only a broken hilly slope, hills, zonal soil type is chestnut soil [20].

\subsubsection{Sample collection and processing}

The 192 copies of simonii green vegetables' roots, stems, leaves from three loose sides of the road and samples of $384(2 \times 192)$ copies from the area around the root rhizosphere soil [12] were collected in the western region of Inner Mongolia National Highway G210, G110 and G109 within $20 \mathrm{~m}$ on both sides of the plant and soil samples by plum-shaped distribution (Figure 1). 


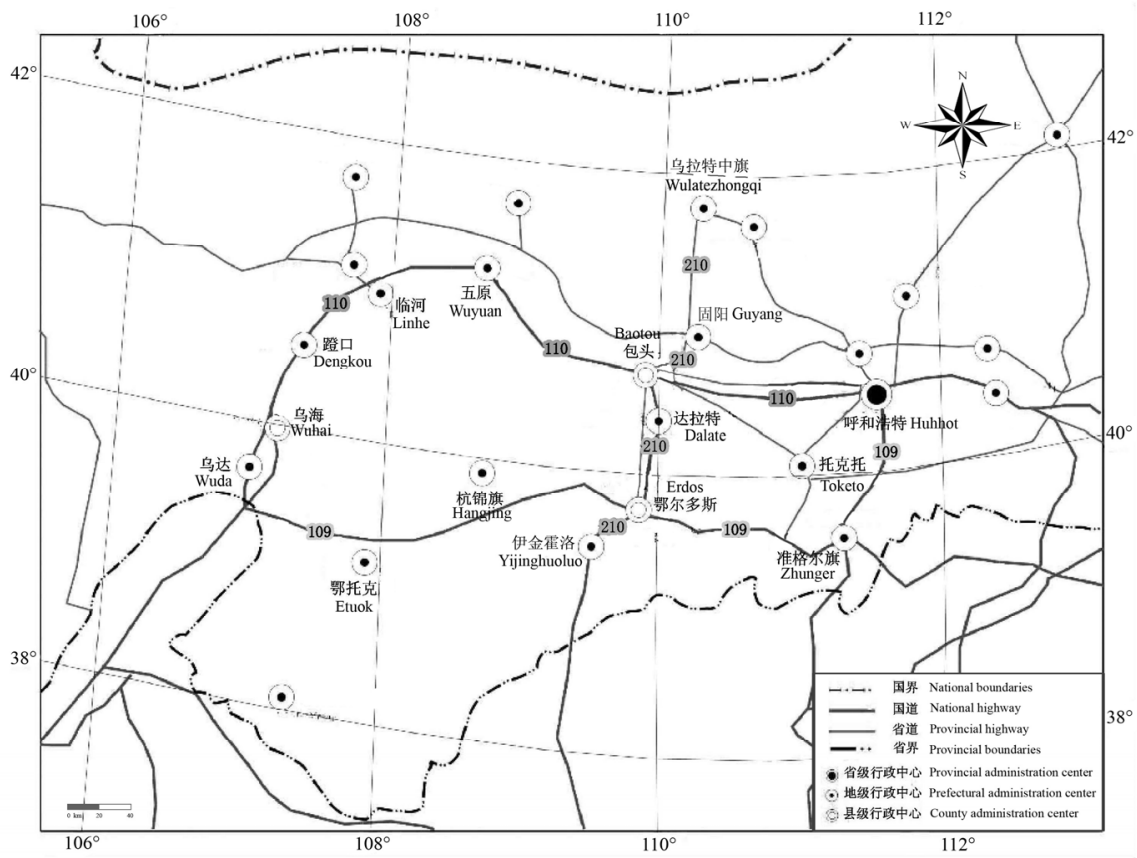

Fig. 1. The map of the sampling station.

And the simultaneous acquisition of the plants as control (CK) is from relatively clean area around the off-road and industrial pollution. Samples of plants was washed with distilled water. Plant roots, stems, leaves and rhizosphere soil samples were naturally air-dried, ground, sieved, bagged, spared, and cold stored [21].

\subsubsection{Determination}

Plant (roots, stems and leaves mixed sample, and overall) and soil heavy metal content was assessed by using atomic absorption spectrophotometer Spectr AA DUO, AF 610A, atomic fluorescence spectrometer; traces of heavy metals $\mathrm{Cd}, \mathrm{Pb}, \mathrm{Cu}, \mathrm{Zn}, \mathrm{Ni}, \mathrm{Cr}$ were determined by dry ash method, and perform $\mathrm{GB} / \mathrm{T} 5009$ in $\mathrm{Cd}, \mathrm{Pb}, \mathrm{Cu}, \mathrm{Zn}, \mathrm{Ni}, \mathrm{Cr}$ atomic absorption spectrometry determination in a muffle oven $500^{\circ} \mathrm{C}$ dry ashing, with 1:1 nitric acid dissolved in $2 \mathrm{ml}$. The way of metal determination is as follows: the plant samples adopt nitric acid perchloric acid digestion, atomic fluorescence spectrometry; $\mathrm{Hg}$ uses aqua regia digestion, atomic fluorescence spectrometry; Se uses nitric acid - perchloric acid digestion, atomic fluorescence spectrometry; rhizosphere soil of heavy metals $\mathrm{Cu}, \mathrm{Zn}, \mathrm{Pb}, \mathrm{Ni}$ and $\mathrm{Cr}$ speciation experiment uses synchronized Tessier sequential extraction method [22] for the determination of the specific processes shown in Figure 2. Soil $\mathrm{pH}$ measured with $\mathrm{pH}$ meter method, the soil and water ratio of 1:1 [21]. 


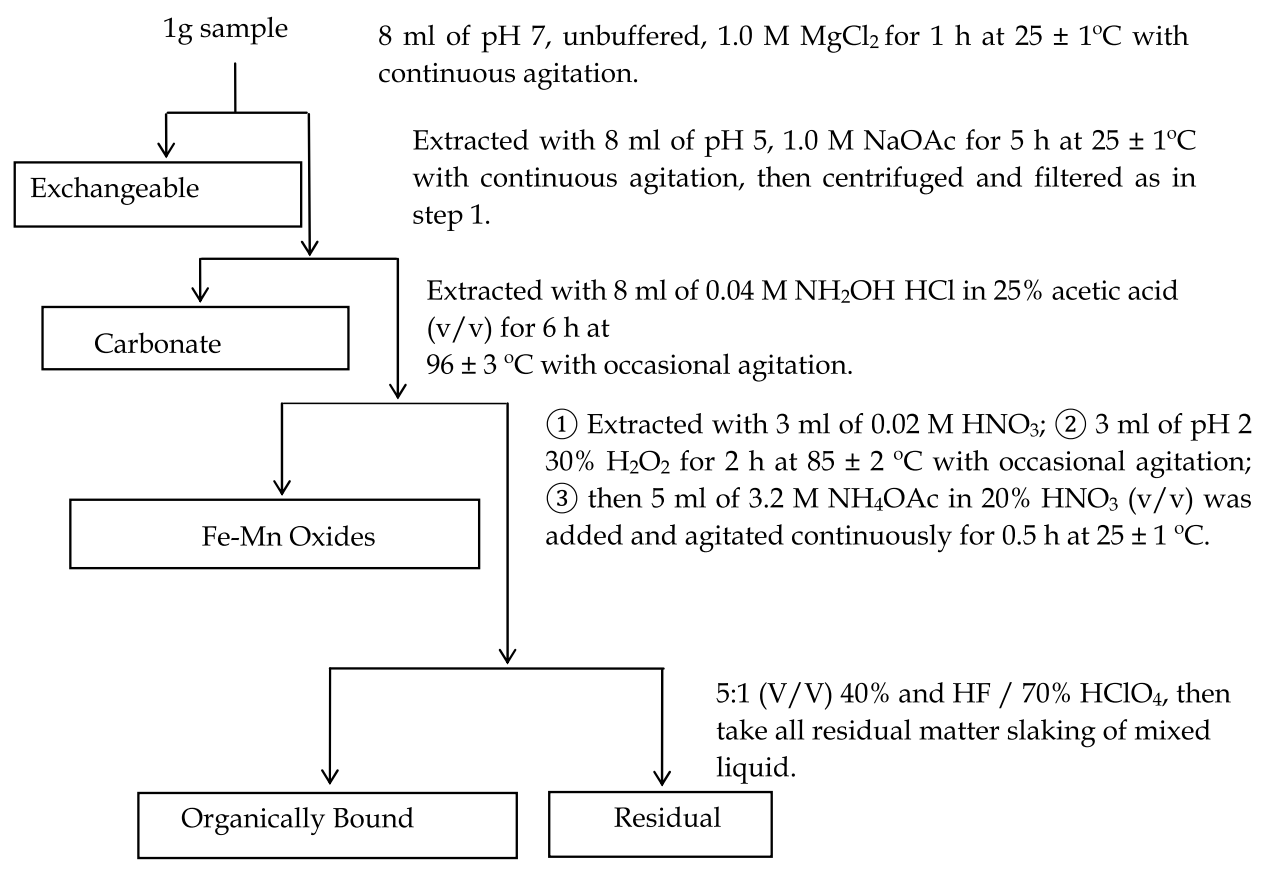

Fig. 2. Sequential extraction procedure for the speciation of heavy metal in sediment.

\section{Results and analysis}

By comparison among the main green vegetable's mixed samples of roots, stems, leaves in pine and poplar along the highway from the western Inner Mongolia with heavy metals in the background medium value of plants' rhizosphere soil [23' 24], the heavy metals of $\mathrm{Cr}, \mathrm{Ni}$, $\mathrm{Cu}, \mathrm{As}, \mathrm{Pb}$ levels in pine and poplar is below the world soil median chemical composition. Meanwhile, the results display the character, that is, the determination value is less than Chinese soil (A level) element of the background value and is less than Inner Mongolia's background value of soil elements and also less than different soil types in study area (meadow soil, brown soil, and chestnut soil). But Zn content $(110.82 \mathrm{mg} \mathrm{kg-1}$ ) of poplar is significantly higher than the world median chemical composition of soil $\left(9.014 \mathrm{mg} \mathrm{kg}^{-1}\right)$ and China Soil (A level) element of the background value $\left(74.2 \mathrm{mg} \mathrm{kg}^{-1}\right)$, as well as Inner Mongolia soil element background values $\left(59.1 \mathrm{mg} \mathrm{kg}^{-1}\right)$. Simultaneity, Zn content of poplar is significantly higher than the study area in different soil types (such as meadow soil (59.10 $\left.\mathrm{mg} \mathrm{kg}^{-1}\right)$, brown soil (56.2 $\left.\mathrm{mg} \mathrm{kg}^{-1}\right)$ and chestnut soil $\left(66.9 \mathrm{mg} \mathrm{kg}^{-1}\right)$; While Zn content of the pine $\left(77.48 \mathrm{mg} \mathrm{kg}^{-1}\right)$ is close to the Chinese soil (A level) element of the background value, but it is higher than different types of soil meadow in the study area.

Average concentration of heavy metals $\mathrm{Zn}$ and $\mathrm{Hg}$ in green plants and rhizosphere soil is similar, while other elements shown in the rhizosphere soil are higher than average levels in plants, for example, $\mathrm{Cu}$ in the soil content of plant is 1.6 times; The content of $\mathrm{Pb}$ and $\mathrm{As}$ in the soil is 7 times the plant; $\mathrm{Cd}, \mathrm{Cr}, \mathrm{Ni}$ in the soil are 10 times as in plants. The soil is alkaline 
in study area where the soil $\mathrm{pH}$ is 8.1 . Heavy metals in different plants are relevant to soil $\mathrm{pH}$ and to the plant's selective absorption of different heavy metals and to the certain speciation of heavy metals in the soil [25]. Delorme et al [26] state that the excess accumulation of blue food is a plant containing the rhizosphere of Thlaspi caerulescens than Trifolium pratense rhizosphere microorganisms, including heavy metals $\mathrm{Cd}$ and $\mathrm{Zn}$-resistant bacteria more than is due to lower $\mathrm{pH}$ of the rhizosphere.

There are differences in the content of heavy metals in different organs of plants, and this is also reflected in differences between different plants. For lobular, $\mathrm{Hg}$ distribution in stems and leaves and roots is more consistent. $\mathrm{Cd}, \mathrm{Cu}, \mathrm{Zn}$, As and Se content is higher in the leaf stems and leaves than the roots; For pine, $\mathrm{Hg}$ content is evenly distributed among the stems, leaves and roots; $\mathrm{Pb}, \mathrm{Cr}, \mathrm{Ni}, \mathrm{Cu}$ in the stems and leaves were higher than in the root; $\mathrm{Cd}, \mathrm{Zn}$ and As were higher than in the roots stems and leaves. This difference displays the direct relationship between the elements in the soil and speciation of metals and the plant's selective absorption of various elements.Generally, contents of heavy metals in different organs at different levels of plants follow the heirarchy of $\mathrm{Zn}>\mathrm{Cu}>\mathrm{Ni}, \mathrm{Cr}, \mathrm{As}, \mathrm{Pb}>\mathrm{Cd}>\mathrm{Hg}$.

The same plant in different organs were also exhibit different degrees of heavy metal enrichment in its different organs. the content ratio of the three kinds of heavy metals $\mathrm{Cr}, \mathrm{Ni}$ and $\mathrm{Pb}$ in simonii is greater than 1 but the content ratio of $\mathrm{Cu}, \mathrm{Zn}, \mathrm{As}$ and $\mathrm{Cd}$ in the of stems and leaves and roots is less than 1.(roots). while the content of $\mathrm{Cr}, \mathrm{Ni}$ and $\mathrm{Pb}$ in the aboveground parts of simonii (stems and leaves is stronger than that in the underground parts (roots).Meanwhile, the aerial parts (stems and leaves) of $\mathrm{Cu}, \mathrm{Zn}, \mathrm{As}$ and $\mathrm{Cd}$ enrichment is weaker than the underground part (root). As previous studies showed, $\mathrm{Cu}, \mathrm{Zn}, \mathrm{Pb}, \mathrm{Cd}$ accumulated in the aerial parts of woody plants is greater than the amount seen in underground parts, and the cumulative amount of Mn element is greater than the underground part of the aerial parts [27]. The primary organ to observe heavy metals in plants is the root, and when the presence of heavy metals in air pollution is high, the plant's leaves can also absorb a significant amount of metal [28].

There is a large difference in heavy metals distributed over different species, and absorption and utilization behavior varies over different environments and different plant cell types [2934]. Exchangeable, carbonate bound, Fe-Mn oxides and organic matter bound heavy metals in plants can be directly or in a certain redox conditions, absorbed and utilized [35-37].

\section{Discussion}

Along the highway of western Inner Mongolia, studies on the main green vegetable, leaf pine, rhizosphere Yang, heavy metal content, distribution, morphology and soil heavy metal bioavailability draw the following conclusions:

1. The green plants in roadside of heavy metals content for $\mathrm{Cr}, \mathrm{Ni}, \mathrm{Cu}, \mathrm{As}, \mathrm{Pb}$ is lower than the background value. However, $\mathrm{Zn}$ content was significantly higher than background values. Rhizosphere soil of heavy metals adsorption of $\mathrm{Cd}$ was the highest.

2. There are some differences in heavy metals perceived in the plant content of different organs of the body, but this is also reflected in the difference exhibited between different plants. With the increasing atomic number $(\mathrm{Cr} \rightarrow \mathrm{Pb})$, two kinds of heavy metals in the roots and stems of poplar and pine have shown " $\mathrm{N}$ " shaped changing 
tendency. and In addition, heavy metals in different plants and in the different organs have the tendency of $\mathrm{Zn}>\mathrm{Cu}>\mathrm{Ni}, \mathrm{Cr}, \mathrm{As}, \mathrm{Pb}>\mathrm{Cd}>\mathrm{Hg}$.

3. The different organs of the same plant have various degrees of enrichments in the different heavy metals. Five kinds of heavy metals' availability phase in the plants' rhizosphere soil are different in the total amount of the percentage in sequence and heavy metals in different organs of the different plants.

4. The study reveals that the plants' absorption and utilization of heavy metal in rhizosphere soil is relevant to the percentage of availability phase, that is to say, the greater the percentage of availability phase is, the bigger enrichment of the heavy metal in the plants appears under a certain environmental condition where plants' transpiration pull and the transportation of water and nutrient shows the equal characteristics along the highway of western Inner Mongolia.

\section{Acknowledgments}

This work was funded by the Inner Mongolia Natural Science Foundation of China (No. 2011MS0501),by the Inner Mongolia Grassland Elite Foundation of China (201140) ,by the Inner Mongolia Talent Development Foundation of China (2011RC1228) The Postdoctoral Science Foundation of China (20060400551) and .We are very grateful to Emmy Camada of Chinese Culture Center of San Francisco in USA for the comment on draft and grammar about the manuscript. Meanwhile, we thank Cui Yan and Liu Jianping for their support in determination of heavy metal at Inner Mongolia Academy of Agricultural Science, and colleagues Mao Jianshuai, Wang zala for their assistance in the fieldwork.

\section{References}

[1] Dai S G, Yuan G C, Wang X R. 1997. Environmental Chemistry, Beijing: Heigher Education Press, $.217 \sim 130$.

[2] He S Y, Jing Y Y. 2000.Environmental Chemistry (3rd edition), Shanghai: East China University of Science and Technology Press, $127 \sim 130$.

[3] Wei Z Y, Chen T B. 2001, Hyperaccumulators and phytoremediation of heavy metal contaminated soil: a review of studies in China and abroad.Acta Ecologica Sinica, 21 (7):1196 1203.

[4] Lu Y S, Luan S J, Zhu Y. 2001. Aanalyse of Environmental influence, Beijing:Higher education press, $145 \sim 180$.

[5] Münch D. 1992. Soil contamination beneath asphalt roads by polynuclear aromatic hydrocarbons, zinc, lead and cadmium. Science of the Total Environment, 126(1/2):49 60 .

[6] Teichman J. 1993. A survey of lead contamination in soil along interstate 880, Alamed County, California. American Industrial Hygiene Association Journal, 54(9):557 559.

[7] Härkönen J, Valkonen E, Kukkonen J, Rantakrans E, et al. 1995. An operational dispersion model for prediction pollution form a road.International Journal of Environment and Pollution, 5(4/6):602 610 .

[8] Volker R. 2002. Influence of heavy metals on the microbial degradation of diesel fuel. Chemosphere, 49(6):559 568. 
[9] Unal A. 2004. Quantification of highway vehicle emissions hot spots based upon onboard measurements.Journal of the Air \& Waste Management Association, 54 (2):130 140 .

[10] Jamriska M. 2004. Diesel bus emissions measured in a tunnel study. Environmental Science \& Technology, 38:(24):6701 6709.

[11] Pulford I D. 2003. Phytoremediation of heavy metal-contaminated land by trees.Environment International, 29(4):529 540.

[12] Chen H M, Chen N Y, Chen Y X, et al. 1996. Heavy Metal Pollution of Soil-plant System.Beijing:Science Press, $210 \sim 247,314 \sim 317$.

[13] Macleod M. 2004. Application of contaminant fate and bioaccumulation models in assessing ecological risks of chemicals: a case study for gasoline hydrocarbons.Environmental Science \& Technology, 38(23):6225 6233.

[14] Yin Y L, Song J, Luo Y M. 2005. Assessment on variation of heavy metals in the greenbelt soils alongside urban-rural roadway in Nanjing city. Acta Pedologica Sinica, 42(2):206 209.

[15] Zhu J J, Cui B S, Yang Z F, et al. 2006. Spatial distribution and variability of heavy metals contents in the topsoil along roadside in the Longitudinal Range-Gorge Region in Yunnan Province.Acta Ecologica Sinica, 26 (1):146 153.

[16] Cheng X, Yu F, Peng S S, et al. 2006. Study on vertical change of highway side slope plllution with heavy metal in Karst area Carsologica Sinica, 25(3):242 245

[17] Wang Z L, He J, Zhi Y B, et al. 2006b, The distribution characteristics of heavy metals pollutants in soil-plant system along highway, Journal of Nanjing Forestry University (Natural Science Edition), 30(4):15 20.

[18] Cai Z Q, Ruan H H, Ye J Z. 2001, A preliminary study on the absorption and accumulation in Oak (Quercus variabilis) stand in suburb of Nanjing. Journal of Nanjing Forestry University (Natural Science Edition), 25(1):18 22.

[19] Zhang Q M, Zhao M. 2003. The analyzing and appraising if the traffic actuality in Inner Mongolia.Economic Geography, 23(1):102 105,112.

[20] Liu Z L. eds. 1985, Inner Mongolia Vegetation, Beijing: Science Press, 332 367.

[21] Bao S D. 2005. Soil and Agricultural Chemistry Analysis (3rd edition).Beijing:Chinese Agricultural Press. $14 \sim 22,178 \sim 199$.

[22] Tessier A, Campbell P G C, Bisson M. 1979. Sequential extraction procedure for the speciation of particulace trace metals. Analytical Chemistry, 51:844 $\sim 851$.

[23] Jia Z B, Huo W Y, Zhao Z J,Tao S. 2000. Secondary phase enrichment factor for evaluation of heavy metal pollution of sediment in the Chai river. Acta Scientiarum Naturalium Universitatis Pekinensis, 36(6):808 812.

[24] Wei F S. 1990. The element background values of Chinese soil. Beijing: Chinese Environmental Science Press. $20 \sim 86,330 \sim 380$.

[25] Li X Y. 2001. Soil Chemistry, Beijing: Higher Education Press, $387 \sim 398$.

[26] Delorme T A, Gagliardi J V, Angle J S, et al. 2001. Influence of the zinc hyperaccumulator Thlaspi caerulescens J. \& C. Presl and the nonmetal accumulator Trifolium pratense L. on soil microbial populations. Canadian Journal of Microbiology, 47(8):773 776

[27] Sun F, Zhong Z C. 1998. Accumulation and biological cycle of heavy metal elements in Gordonia acuminata evergreen broad-leaved forest of mountain Jinyun in Chongqing.China Environmental Science, 18(2):111 116 
[28] Wang D Y, Mou S S, Qing C L. 1998. The effect of atmospheric mercury on the accumulation of mercury in soil-plant system. China Environmental Science, 18 (2):194 198

[29] Zhang H, Ma D S. 1998. An approach to the characteristics of heavy metal phase as well as the capacity of desorption and adsorption in soil about heavy metal pollution formed by highway, Environmental Chemistry, 17(6):564 568.

[30] Dong Y T, Cui Y S, Wang Q R. 2003. Uptake of Cd, Zn and Pb by two susceptible plants under monoand multiple-contamination conditions.2003,Acta Ecologica Sinica, 23 (5):1018 1024.

[31] Chen H M. 2002. Behavior of Chemicals in Soils and Its Relation to Environmental Quality, Beijing: Science Press, $1 \sim 22,46 \sim 78$.

[32] Zhang H, Ma D S. 1997. Fractionation of heavy metals in soils from Nanjing.Acta Scientiae Circumstantiae, 17 (3):346 351.

[33] Wu C N, Wang Y, Zhao L. 2004. The speciation characteristics of heavy metals pollutants along highway in Shanghai-Nanjing (Zhenjiang segment), Environmental Chemistry, 23(4):465 466.

[34] Chen H M. 2005. Environmental Agrology, Beijing: Science Press, $219 \sim 236$.

[35] Ernst W H O. 1996. Bilavailability of heavy melals and deconrarniation of soils by plants. Applied Geochemistry, 11:163 167

[36] Zhi Yingbiao, Wang Zailan, Wang Zhongsheng, et al. 2007. The absorption and accumulation of heavy metals pollutants in plant along highway in western Inner Mongolia. Acta Ecologica Sinica, 27 (5):1863 - 1872.

[37] Zhi Yingbiao, Wang Zailan, Ma Zhong, et al. 2007. The speciation and bioavailability of heavy metals pollutants in soil along highway in Erdos. Acta Ecologica Sinica, 27 (5): 2030 - 2039. 


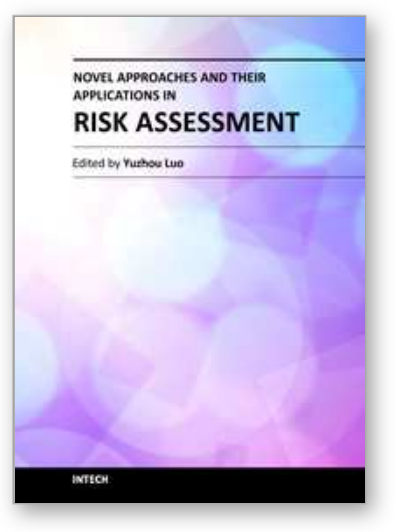

\author{
Novel Approaches and Their Applications in Risk Assessment \\ Edited by Dr. Yuzhou Luo
}

ISBN 978-953-51-0519-0

Hard cover, 344 pages

Publisher InTech

Published online 20, April, 2012

Published in print edition April, 2012

Risk assessment is a critical component in the evaluation and protection of natural or anthropogenic systems. Conventionally, risk assessment is involved with some essential steps such as the identification of problem, risk evaluation, and assessment review. Other novel approaches are also discussed in the book chapters. This book is compiled to communicate the latest information on risk assessment approaches and their effectiveness. Presented materials cover subjects from environmental quality to human health protection.

\title{
How to reference
}

In order to correctly reference this scholarly work, feel free to copy and paste the following:

Lu Zhanyuan, Zhi Yingbiao, Wang Zai-lan, Hua Yupeng, Hong Ge, Emmy Camada and Yao Yiping (2012). Absorption and Accumulation of Heavy Metal Pollutants in Roadside Soil-Plant Systems - A Case Study for Western Inner Mongolia, Novel Approaches and Their Applications in Risk Assessment, Dr. Yuzhou Luo (Ed.), ISBN: 978-953-51-0519-0, InTech, Available from: http://www.intechopen.com/books/novel-approaches-andtheir-applications-in-risk-assessment/the-absorption-and-accumulation-of-heavy-metals-pollutants-in-soilplant-systems-along-highway-a-cas

\section{INTECH}

open science | open minds

\section{InTech Europe}

University Campus STeP Ri Slavka Krautzeka 83/A 51000 Rijeka, Croatia Phone: +385 (51) 770447 Fax: +385 (51) 686166 www.intechopen.com

\section{InTech China}

Unit 405, Office Block, Hotel Equatorial Shanghai No.65, Yan An Road (West), Shanghai, 200040, China 中国上海市延安西路65号上海国际贵都大饭店办公楼405单元 Phone: +86-21-62489820

Fax: +86-21-62489821 
(C) 2012 The Author(s). Licensee IntechOpen. This is an open access article distributed under the terms of the Creative Commons Attribution 3.0 License, which permits unrestricted use, distribution, and reproduction in any medium, provided the original work is properly cited. 